\title{
L'influence de la force de Coriolis sur les courants de marée. dans un estuaire exponentiel
}

\author{
Coriolis effects on the tidal flow \\ in an exponential estuary
}

\author{
par M. R. ABBOT
}

HYMAULICG RTSEARGH STATION, WALLINGFOND, ANGLETURTE

\begin{abstract}
Cetle communication présente une muthode pour te calcul simple et approché, en tenant comple de la rotation de la terre, des courants de marée dans un estuaire dont la profondeur moyenne est constante et dont la largeur varie suivant une loi exponentielle. On fait intervenir les frottements par la linéarisation de Lorentz de la loi de Chézy. On démontre que la dénivellation maximale entre les deux rives de l'es. thaire correspondant $\dot{a}$ nne onde progressive s'exprime par nue formule identique $\dot{a}$ celle qui correspond a un chenal uniforme et sans frottements, mais que la différence d'amplitude peut etre rendue sensiblement plas faible $p a r$ un dephasage. On applique cette théorie à une section de la Tamise et on demontre que la difference d'amplitude n'est que d'environ $u r$ tiers de la denivellation maximale.
\end{abstract}

\begin{abstract}
This paper gives a simple approximate treatment of the tidal fiow in an estuary, of constant mean depth and exponential width, taking the rotation of the earth into accomnt. The frictional resistance is represented by Lorentz's linearisation of Chezy's law. II is shown that the maximum difference of level across the estuary for a progressive wave is given by the same formula as for a uniform frictionless channel, but, due to a difference of phase, the difference of amplitude can be considerably less. The theory is applied to a section of the Thames Estuary and it is shown that the amplitude difference is only about a third of the maximum difference of level.
\end{abstract}

\section{I. - INTRODUCTION}

Il est bien connu que la rotation de la terre a pour effet d'augmenter l'amplitude de la marée vers la droite dans un estuaire et de la diminuer vers la gauche. Cela est le cas pour un observateur situé dans l'hémisphère nord et qui regarde vers l'amont, les phénomènes étant inversés dans l'hémisphère sud.

La théorie des ondes progressives se propageant dans un canal tournant, de section uniforme et en l'absence de frottements, a été présentée pour la première fois par lord Kelvin (Thompson, 1879). Ces ondes de Kelvin sont du type :
It is well known that the rotation of the earth has the effect of increasing the tidal range on the right hand side of an estuary and decreasing it on the left. This is with respect to an observer looking upstream in the Northern hemisphere: the reverse situation applies in the Southern hemisphere.

The theory of progressive waves travelling along a rotating frictionless channel of uniform section was first given by Lord Kelvin (Thompson, 1879). These Kelvin waves are of the form :

$$
\eta=\eta_{0} e^{(-2 \Omega y / \sqrt{g} \vec{g})+i(\omega t-k x)}, \quad u=u_{0} e^{(-2 \Omega y / \sqrt{g} \bar{h})+i(\omega t-k x)}
$$


Q étant la vitesse angulaire de rolation (voir Lamb (1932), § 208). Quand on néglige l'influence de la rotation sur les mouvements verticaux, la solution est valable pour un canal situé à n'importe quelle latitude ( $)$ ) sur une sphère tournante, si on remplace $\Omega$ par $\Omega$ sin o. La célérité de l'onde $(\omega / k=\sqrt{g h)}$ et le rapport entre $\eta$ et $u\left[u_{0}=\sqrt{(g / h)} \eta_{0}\right]$ ne sont pas modifiés par la rotation, mais on peut constater que l'amplitude de l'onde près de la rive droite du canal est plus grande que celle de sa rive gauche, la différence élant de $\eta_{0}\left\lceil 1-e^{(-\beta b / \sqrt{g h})}\right]$, avec $\beta=2 \Omega$ sin $\varphi$ et $b$ étant la largeur constante du canal. Puisque normalement $\beta b / \sqrt{g h}$ est très petit, cette différence d'amplitude peut s'écrire $\eta_{0} \beta b / \sqrt{g h}$ ou, ce qui est équivalent : $u_{0} \beta b / g$; cependant la phase ne varie pas entre les deux rives.

Souvent on applique ce résultat, hors de ses limites de validité, aux estuaires et golfes soumis à la marée, où les efforts de frottement, la réflexion des ondes et la variation de la section rendent les conditions réelles plus compliquées que celles dont on a tenu compte en établissant la formule

Dans cette communication, on considère un estuaire idéalisé dont la largeur varie selon une loi exponentielle et qui a une profondeur moyenne constante (beaucoup d'estuaires réels approchent de ces conditions). On fait intervenir la résislance due aux frottements en la faisant proportionnelle à la vitesse. On peut également introduire une onde réfléchie par la condition limite $u=0$ à $x=\mathrm{L}$, si la largeur de l'estuaire à $x=\mathrm{L}$ est assez faible pour qu'il n'existe pas une variation latérale due à la force de Coriolis; sinon, comme pour le canal uniforme, on ne peut pas superposer deux ondes progressives de telle façon qu'on obtienne $u=0$ à une barrière $x=\mathrm{L}$.

Les équations obtenues sont résolues approximativement el la solution indique que les frottements et le rétrécissement progressif ont pour résultal un déphasage entre les deux rives de l'estuaire. Non seulement l'amplitude de l'onde est plus grande sur la rive droite de l'estuaire que sur la rive gauche, mais, sur la rive droite, il y a un déphasage en avant par rapport à la rive gauche. On démontre que, pour une onde progressive, la dénivellation maximale latérale dans l'estuaire est de $u_{0} \beta b / g$, comme pour un canal latéral sans frottements; mais, étant donné le déphasage, la différence d'amplitude peut avoir une valeur sensiblement plus faible que cette dénivellation maximale. La différence d'amplitude est la quantité la plus importante, puisqu'elle donne la différence entre les hauteurs du plan d'eau de l'estuaire et qu'elle joue un rôle important dans la conception des ouvrages de protection contre les crues. where $Q$ is the angular velocity of rotation; sec for example Lamb (1932), $\$ 208$. If the effect of the rotation on the vertical motion is neglected, the solution holds for a channel at any latitude (ழ) on a rotating sphere if $\Omega$ is replaced by $\Omega \sin \varphi$. The wave velocity $(\omega / k=\sqrt{g h})$ and the relation between $\eta$ and $u\left[u_{0}=\sqrt{(g / h)} \eta_{0}\right]$ are unaffected by the rotation, but, it can be seen that the amplitude of the wave is greater on the right side of the channel than on the left by an amount $\eta_{0}\left[1-e^{(-\beta b / \sqrt{g h)}}\right]$, where $\beta=2 \Omega \sin \varphi$ and $b$ is the constant width of the channel. Since $\beta b \sqrt{g h}$ is usually very small, this difference of amplitude can be written as $n_{0} \beta b \sqrt{g h}$ or equivalently as $u_{0} \beta b / g$; there is, however, no variation of phase across the channel.

This result is frequently applied out of its proper context to tidal estuaries and gulfs, where, due to frictional forces, wave reflection and variation of cross-section, the true situation is more complicated than that assumed in the derivation of the formula.

The present paper considers an idealised estuary which is exponential in width and has constant mean depth (many actual estuaries approximate to these conditions) and the frictional resistance is allowed for approximately by taking it proportional to the velocity. It is also possible to introduce a reflected wave, by a boundary condition $u=0$ at $x=\mathrm{L}$, if the width of the estuary at $x=\mathrm{L}$ is sufficiently small for there to be no variation across it due to the Coriolis force; otherwise, as in a wide uniform channel, it is not possible to superimpose two progressive waves so as to obtain $u=0$ at a barrier $x=\mathrm{L}$.

The equations oblained are solved approximately and the solution shows that, due to friction and taper, there is a phase difference across the estuary. The wave not only has a greater amplitude on the right than on the left of the estuary, but the phase on the right is ahead of that on the left. It is shown, for a progressive wave, that the maximum difference of level across the estuary is $u_{0} \beta b / g$, as for a uniform frictionless channel; but, due to the difference of phase, the difference in amplitude may be considerably less than this. The difference in amplitude is the more important quantity, since it gives the difference in the ultimate height of the water surface across an estuary, and is of consequence in the design of flood protection works. 
Les résultats de cette communication peuvent également être intéressants pour l'estimation de l'erreur due à la représentation incorrecte de la force de Coriolis sur un modèle d'un estuaire large. La ritesse angulaire effective d'un modèle étant identique à celle de l'estuaire réel (si le modèle et l'estuaire sont situés à une latitude sensiblement identique), il faut, pour représenter correctement la force de Coriolis, augmenter la vitesse angulaire du modèle en fonction de l'échelle des temps' adoptée.
The results of this paper may also be of use in estimating the error involved in a model of a wide estuary, due to the incorrect representation of the Coriolis force. The effective angular velocity of a model is the same as that of the actual estuary (assuming the model and the estuary are in approximately the same latitude), whereas, in order to represent the Coriolis force correctly, the angular velocity of the model should be scaled up in conformity with the time scale adopted.

\section{II. - THÉORIE \\ II. - THEORY}

Dans ce chapitre, nous obtenons la solution approchée des équations de mouvement correspondant aux courants de marée dans un estuaire exponertiel d'une profondeur moyenne constante. On tient compte de l'effet de Coriolis dû à la rotation de la terre, et on représente approximativement la résistance due aux frottements par la linéarisation de Lorentz de la loi de Chézy.

On prend l'axe de l'estuaire pour axe des $x$, le sens positif étant dirigé vers l'amont, et l'axe des $y$ est pris horizontalement en travers de lestuaire pour former un système orienté à droite. Si la largeur de l'estuaire à un point donné est $b(x), y$ varie entre $-1 / 2 b$ et $1 / 2 b$ entre les deux rives. Pour des mouvements de marée limités à un estuaire, la vitesse transversale dans le sens des $y$ peut être considérée comme étant nulle; donc, les équations des quantités de mouvement sont :
In this section we derive an approximate solution of the equations of motion describing the tidal flow in an exponential estuary of constant mean depth. The Coriolis effect due to the rotation of the earth is taken into account and the frictional resistance is represented approximately by Lorentz's linearisation of Chezy's law.

The $x$-axis is taken along the centre line of the estuary, the positive direction upstream, and the $y$-axis is taken horizontally across the estuary to form a right handed system; if $b(x)$ is the width at any point, $y$ varies from - $1 / 2 b$ to $1 / 2 b$ across the estuary. For tidal motion confined to an estuary, the transverse velocity in the $y$-direction can be taken as zero; the momentum equations are then :

$$
\begin{gathered}
(\partial u / \partial t)+g(\partial \eta / \partial x)+f u=0 \\
g(\partial \eta / \partial y)+\beta u=0
\end{gathered}
$$

ut étant la vitesse de l'eau, $\eta$ la hauteur du plan d'eau, $\beta=2 \Omega \sin \varphi$ le paramètre de Coriolis (dans lequel $\Omega$ est la vitesse angulaire de la terre, $\phi$ est la latitude de l'estuaire) et $f$ le coefficient de proportionnalité entre l'effort des frottements par unité de volume et la vitesse; selon Lorentz, $f=8 g u_{\max } / 3 \pi h \mathrm{C}^{2}$ où $u_{\max }$ est le courant de marée maximum qui se manifeste pendant un cycle de marée, $h$ la profondeur moyenne et $C$ la constante de Chézy.

L'équation de continuité est : where $u$ is the velocity of the water, $\eta$ the height of the water surface, $\beta=2 \Omega \sin \varphi$ is the Coriolis parameter where $Q$ is the angular velocity of the earth and $\varphi$ the latitude of the estuary, and $f$ is the constant of proportionality between the frictional force per unit volume and the velocity; according to Lorentz $f=8 g u_{\max } / 3 \pi h \mathrm{C}^{2}$ where $\| u_{\max }$ is the maximum tidal current occurring during a tidal cycle, $h$ is the mean depth and $C$ is Chezy's constant.

The continuity equation is :

$$
\frac{\partial}{\partial x} \int_{-b / 2}^{b / 2} u h d y+\int_{-b / 2}^{b / 2} \frac{\partial \eta}{\partial t} d y=0
$$


đui se ramène à :

which reduces to :

$$
-(1 / 2) \alpha b h\{u(x, b / 2, t)+u(x,-b / 2, t)\}+h \int_{-b / 2}^{b / 2} \frac{\partial u}{\partial x} d y+\int_{-b / 2}^{b / 2} \frac{\partial \eta}{\partial t} d y=0
$$

si on fait l'hypothèse que la profondeur moyenne $h$ est constante le long de l'estuaire et que la largeur varie exponentiellement selon $b=b(o) e^{-\alpha x}$.

Pour une onde progressive, nous posons : if it is assumed that the mean depth $h$ is constant along the estuary and the width varies exponentially as $b=b(o) e^{-a: x}$.

For a progressive wave we put:

$$
\eta=\eta_{0} \mathbf{F}(y) e^{i(\omega t-k i t)}, \quad u=u_{0} \mathbf{F}(y) e^{i(\omega t-l w x)}
$$

$2 \pi / \omega$ étant la période de la marée et $\mathrm{F}, k, \eta_{0}, u_{0}$, étant des valeurs à déterminer.

Les équations (1), (2) et (4) se ramènent respectivement à :

$$
\begin{gathered}
(f+i \omega) u_{0}=i g k \eta_{0} \\
g r_{i 0} \mathrm{~F}^{\prime}(y)+\beta u_{0} \mathrm{~F}(y)=0 ; \\
(1 / 2) \alpha b h u_{0}\{\mathrm{~F}(b / 2)+\mathrm{F}(-b / 2)\}=i\left(\omega \eta_{0}-k h u_{0}\right) \int_{-u / 2}^{b / 2} \mathrm{~F}(y) d y
\end{gathered}
$$

De (6) et (7) on obtient :

From (6) and (7) :

$$
\mathrm{F}(y)=\exp \left(-\frac{\beta u_{0}}{g \eta_{0}} y\right)=\exp \left(-\frac{\beta k y}{\omega-i f}\right)
$$

On peut voir facilement qu'en général, (8) et (9) sont incompatibles, puisque $\mathrm{F}(y)$, donné par (9), ne satisfait pas (8) pour n'importe quelle valeur constante de $k$. Cela implique qu'il n'existe pas de solutions simples et exactes du type (5) pour notre problème. Cependant, si $\mid \beta k y / \omega-$ if $\mid$ est suffisamment petit $(<0,2$, par exemple), on peut remplacer (9) approximativement par :

$$
F(y)=1-\frac{\beta k y}{\omega-i f}
$$

Pour que cette expression soit une bonne approximation de $x$ positive, et puisque la valeur maximale de $y$ est $1 / 2 b$, il faut que :

$$
\beta|k| b(0)<0,4 \sqrt{\omega^{2}+f^{2}}
$$

Cette condition peut s'écrire très approximativement $\beta b(0)<0,4 \sqrt{g h}$, ce qui est valabJe pour la plupart des applications; par exemple, si $h=100$ pieds et $\varphi=50^{\circ}, b(0)$ peut atteindre 65 kilomètres. Avec cette approximation, $F(y)$, et par conséquent $\eta$ et $u$ également, varient linéairement dans la direction transversale et la valeur moyenne de $F(y)$ sur n'importe quelle section est $F(0)$; de plus, (8) et (9) ne sont pas incompatibles pour cette approximation; en effet, (8) et (9) donnent :
It can easily be seen that (8) and (9) are in general inconsistent in that $\mathrm{F}(y)$ given by (9) does not satisfy (8) for any constant value of $k$. This implies there are no simple exact solutions of the type (5) to our problem. However, if $\mid \beta k y / \omega-$ if $\mid$ is sufficiently small $(<0.2$ say) we can replace $(9)$ by : approximately; since the maximum value of $y$ is $1 / 2 b$, we require for this to be a good approximation for positive $x$ that:

$$
\beta|k| b(o)<0.4 \sqrt{\omega^{2}+f^{2}}
$$

This condition can be written very roughly as $\beta b(o)<0.4 \sqrt{g h}$, which is satisfied in most applications, for example if $h=100 \mathrm{ft}$ and $0=50^{\circ}, b(o)$ can be up to 40 miles. With this approximation, $\mathbf{F}(y)$, and therefore $\eta$ and $u$ also, vary linearly across the estuary and the mean value of $F(y)$ over any cross-section is $\mathrm{F}(0)$; further, (8) and (9) are not inconsistent to this approximation; in fact (8) and (10) give :

$$
h(\alpha+i k) u_{0}=i \omega \eta_{0}
$$


ce qui est l'équation classique pour les monvements dans l'estuaire en l'absence de la force de Coriolis.

On peut maintenant procéder à la résolution de $(6),(10)$ et (12) : de (6) et (12 nous obtenons:

$$
\frac{f+i \omega}{h(\alpha+i k)}=\frac{g k}{\omega}
$$

et par conséquent : ,

therefore :

$$
k=(1 / 2) i\left\{\alpha \pm \sqrt{\alpha^{2}-4 i(\omega-i f) / g h}\right\}
$$

la racine de (14) ayant une partie réelle positive ( $k_{1}$ par exemple) correspond aux ondes qui se propagent dans le sens des $x$ positifs, tandis que la racine ayant la partie réelle négative correspond aux ondes qui se propagent dans le sens des $x$ négatifs. Posons :

$$
m=\beta /(\omega-i f)
$$

et de (5) et (10), nous obtenons : and from (5) and (10) we have :

$$
\begin{gathered}
\eta=\eta_{0}\left(1-m k_{1} y\right) e^{i\left(\omega t-k_{1} x\right)} \\
u=g\left(m k_{1} / \beta\right) \eta_{0}\left(1-m k_{1} y\right) e^{i\left(\omega t-k_{1} w\right)}
\end{gathered}
$$

pour une onde qui se propage dans le sens des $x$ positifs. Pour la propagation dans le sens des $x$ négatifs, nous obtenons un résultat semblable dans lequel $k_{2}$ et $\eta_{0}^{\prime}$ remplacent $k_{1}$ et $\eta_{0}$ de (16) et (17) respectivement.

Pour une onde progressive qui salisfait $\eta=a e^{i \omega t}$ à $x=0$ et $y=0$, nous avons :

for a progressive wave travelling in the positive $x$-direction. For propagation in the negative $x$-direction we have a similar result with $k_{1}$ and $\eta_{0}$ in (16) and (17) replaced by $k_{2}$ and $\eta_{0}^{\prime}$ respectively.

For a progressive wave with $\eta=a e^{i \omega t}$ at $x=0$, $y=0$, we have:

$$
\eta=a\left(1-m k_{1} y\right) e^{i \omega t}
$$

sur la section transversale $x=0$. Par consé- across the section $x=0$. Therefore, quent:

$$
\eta_{\mathrm{R}}-\eta_{\mathrm{L}}=a m k_{1} b e^{i \omega t}
$$

$\eta_{\mathrm{I}}$ étant la valeur de $\eta$ sur la rive droite à $x=0$, $y=-b / 2$, et $\eta_{\mathrm{L}}$ étant la valeur de $\eta_{\mathrm{I}}$ sur la rive gauche à $x=0, y=b / 2$. Donc, la dénivellation transversale maximale dans l'estuaire est :

where $\eta_{\mathrm{r}}$ is the value of $\eta_{\text {on }}$ the right bank at $x=0, y=-1 / 2 b$, and $r_{L}$ is the value of $\eta$ on the left bank at $x=0, y=1 / 2 b$. The maximum difference in level across the estuary is thus :

$$
\left|\eta_{\mathrm{R}}-\eta_{\mathrm{L}}\right|=a b\left|m k_{1}\right|
$$

Au centre de la section, l'amplitude de la vitesse est:

At the centre of the section the amplitude of the velocity is :

$$
u_{0}=\frac{g a\left|m k_{1}\right|}{\beta}
$$

et par conséquent :

hence :

$$
\left|\eta_{\mathrm{R}}-\eta_{\mathrm{L}}\right|=\frac{u_{0} \beta b}{g}
$$

qui s'accorde avec le résultat correspondant à un canal uniforme sans frottements. Cependant, in agreement with the result for a uniform frictionless channel. However, in the present case, 
les frottements et le rétrécissement progressif de l'estuaire ont pour résultat un déphasage transversal dans ce dernier, et par conséquent la dénivellation maximale n'est pas égale à la différence d'amplitude comme elle l'est dans le cas d'un canal uniforme et sans frotlements. La différence d'amplitude est $\left|\eta_{R}\right|-\left|\eta_{L}\right|$, ce qui est $\leqslant\left|\eta_{R}-r_{1}\right|$; ces deux quantités ne sont égales que s'il n'existe pas un déphasage entre les deux rives de l'estuaire.

En effet, (18) donne :

$$
\left|\eta_{\mathrm{R}}\right|-\left|\eta_{\mathrm{N}}\right|=a\left|1+1 / 2 m k_{1} b\right|-a\left|1-1 / 2 m k_{1} b\right| \div a b \operatorname{Re}\left(m k_{1}\right),
$$

puisqu'en général $1 / 2\left|m k_{1}\right| \cdot b<1$. La différence d'amplitude sur la section de la Tamise considérée au $\$ 3$ n'est qu'un tiers de la dénivellation maximale, bien que le déphasage transversal ne soit que de 140 secondes.

Prenons, comme exemple, des mouvements de marée où intervient une onde réfléchie, les conditions $\eta=\alpha e^{i \omega t}$ à $x=0, y=0$ et $u=0$ a la limite $x=L$ de la région soumise à la marée. On fait l'hypothèse qu'on peut négliger la variation de $u$ en fonction de $y$ sur la section $x=$ L. Cela impose :

$$
\beta|k| b(\mathrm{~L})<0,04 \sqrt{\omega^{2}+f^{2}}
$$

Ce mouvement s'exprime par la somme de deux ondes progressives ayant des sens de propagation opposés; avec les conditions limites, on oblient : due to friction and taper, there is a difference of phase across the estuary, and consequently the maximum difference in level is not the same as the difference of amplitude, as it is for a uniform frictionless channel. The difference in amplitude is $\left|\eta_{R}\right|-\left|\eta_{L}\right|$, which is $\leqslant\left|\eta_{R}-\eta_{L}\right|$; the two quantities are equal only if there is no phase difference across the estuary. In fact from (18),

since $1 / 2\left|m k_{1}\right| b<<1$ in general. Across a section of the Thames, discussed in $\S 3$, the difference of amplitude is only about a third of the maximum difference of level, even though the phase difference across the estuary amounts to only 140 seconds.

As an example of the tidal motion in an estuary involving a reflected wave, we lake the conditions $\eta=a e^{i \omega t}$ at $x=0, y=0$, and $u=0$ at the tidal limit $x=\mathrm{L}$. It is assumed that the variation of $u$ with $y$ across the section $x=L$ is negligible, this requires :

$$
\beta|k| b(\mathrm{~L})<0.04 \sqrt{\omega^{2}+f^{2}}
$$

The motion is taken as the sum of two progressive waves travelling in opposite directions, the boundary conditions give :

$$
\eta_{0}+\eta_{0}^{\prime}=a, \quad k_{1} \eta_{0} e^{-i \hbar_{1} \mathrm{~L}}+k_{2} \eta_{0}^{\prime} e^{-i k_{2} \mathrm{~L}}=0
$$

d'où :

hence :

$$
\eta_{0}=\frac{a k_{2} e^{-i k_{2} \mathrm{~L}}}{k_{2} e^{-i k_{2} \mathrm{~L}}-k_{1} e^{-i k_{2} \mathrm{I}}}
$$

$$
\eta_{0}^{\prime}=\frac{-a k_{1} e^{-i k_{1} I}}{k_{2} e^{-i k_{2} L_{2}}-k_{1} e^{-i k_{1} \mathrm{I}_{*}}}
$$

Ainsi la solution est :

The solution is therefore :

$$
\begin{gathered}
\eta=\frac{a}{\left(k_{2} e^{-i k_{2} \mathrm{~L}}-k_{1} e^{\left.-i k_{1} \mathrm{~L}\right)}\right.}\left\{k_{2}\left(1-m k_{1} y\right) e^{i\left(\omega t-k_{1} x-k_{1} \mathrm{~L}\right)}-k_{1}\left(1-m k_{2} y\right) e^{i\left(\omega t-k_{1} x-k_{1} \mathrm{~L}\right)}\right) \\
u=\frac{a g m k_{1} k_{2}}{\beta\left(k_{2} e^{-i k_{2} \mathrm{~L}}-k_{1} e^{\left.-i k_{1} \mathrm{~L}\right)}\right.}\left\{\left(1-m k_{1} y\right) e^{i\left(\omega t-k_{1} x-k_{2} \mathrm{~L}\right)}-\left(1-m k_{2} y\right) e^{i\left(\omega t-k_{2} x-k_{1} \mathrm{~L}\right)}\right)
\end{gathered}
$$

$k_{1}$ et $k_{2}$ étant donnés par (14) et $m$ par (15). Il est commode de laisser (27) et (28) sous forme complexe et de n'en extraire les parties réelles qu'après un calcul numérique.

Les expressions (27) et (28) donnent facilement la dénivellation et la différence de vitesse entre les deux rives de l'estuaire. Si on prend pour origine le centre de la section considérée, nous obtenons: with $k_{1}$ and $k_{2}$ given by (14) and $m$ by (15). It is convenient to leave (27) and (28) in complex form and to take real parts only at the end of a numerical calculation.

The difference in level and velocity across the estuary at any place and time can easily be obtained from (27) and (28). If the origin is taken at the centre of the section in question, we have:

$$
\eta_{\mathrm{R}}-\eta_{\mathrm{L}}=a m k_{1} k_{2} \frac{b\left(e^{-i k_{2} \mathrm{~L}}-e^{-i k_{1} \mathrm{~L}}\right) e^{i \omega t}}{k_{2} e^{-i k_{2} \mathrm{I}_{2}}-k_{1} e^{-i k_{1} \mathrm{I}_{2}}}
$$


et :

and :

$$
u_{\mathrm{R}}-u_{\mathrm{L}}=-a g m^{2} k_{1} k_{2} \frac{b\left(k_{2} e^{-i k_{1} \mathrm{~L}}-k_{1} e^{-i k_{2} \mathrm{I}}\right) e^{i \omega t}}{\beta\left(k_{2} e^{-i k_{2} \mathrm{~L}}-k_{1} e^{-i k_{1} L}\right)}
$$

Tout calcul de la différence d'amplitude doit tenir compte de la variation de phase entre les deux rives, et celle-ci est déterminée le plus facilement directement à partir de (27).
Any calculation of the difference of amplitude has to take into account the change of phase across the estuary, and it is best obtained direct from (27).

\section{III. - APPLICATION A L'ESTUAIRE DE LA TAMISE \\ III. - APPLICATION TO THE THAMES ESTUARY}

On fixe l'origine au centre de la section de Southend et on utilise les valeurs suivantes des diverses constantes :

$$
\begin{aligned}
& a=2,44 \mathrm{~m}, \omega=1,41 \cdot 10^{-4} \mathrm{~s}^{-1}, \beta=1,14 \cdot 10^{-4} \mathrm{~s}^{-1} \\
& \left(\text { pour } \Omega=7,29 \cdot 10^{-5} \mathrm{~s}^{-1} \text { et } \varphi^{\prime}=51,5^{\circ}\right) \\
& f=2,5 \cdot 10^{-4} \mathrm{~s}-1 \\
& \left(\text { pour } a_{\max }=1,22 \mathrm{~m} / \mathrm{s} \text { et } \mathrm{C}=39,77 \mathrm{~m} / \mathrm{s}\right) \\
& \alpha=3,65 \cdot 10^{-5} \mathrm{~m}^{-1}, h=7,92 \mathrm{~m} \text { et } \mathrm{L}=100 \mathrm{~km} .
\end{aligned}
$$

Quelques-unes de ces valeurs ont été données par Inglis et Allen (1957).

De (14), nous obtenons :

$$
\begin{aligned}
k_{1}=(1,31+0,23 i) \times 10^{-5} \\
k_{2}=(-1,31+3,70 i) \times 10^{-5} \mathrm{~m}^{-1}
\end{aligned}
$$

et de (15) :

$$
m=0,19+0,34 i
$$

Pour que (16) soit applicable à la Tamise, (11) impose :

$$
\beta\left|k_{1}\right| b(o)<0,4 \sqrt{\omega^{2}+f^{2}},
$$

où $b(o)<80 \mathrm{~km}$ environ. D'autre part, si, comme en (27), on tient compte des ondes réfléchies, (11) et (24) imposent :

$$
\begin{array}{r}
\beta\left|k_{2}\right| b(o)<0,4 \sqrt{\omega^{2}+f^{2}}, \\
\beta\left|k_{2}\right| b(\mathrm{~L})<0,04 \sqrt{\omega^{2}+f^{2}},
\end{array}
$$

où $b(o)<32 \mathrm{~km}$ et $b(L)<3 \mathrm{~km}$ environ. En fait, $b(o)=6,5 \mathrm{~km}$ et $b(\mathrm{~L})=61 \mathrm{~m}$, ce qui veut dire qu'on peut appliquer la théorie du $\$ 2$ à cet exemple ef qu'on doit en obtenir une bonne approximation.

On procède maintenant au calcul de l'effet Coriolis entre les rives de l'estuaire de la Tamise dans le voisinage de Southend $(x=0)$ en utilisant les diverses formules des $\S \S 1$ et 2.
The origin is taken at the centre of the Southend section and the following values of the various constants are assumed :

$$
\begin{aligned}
& a=8 \mathrm{ft}, \omega=1.41 \times 10^{-4} \mathrm{sec}^{-1}, \beta=1.14 \times 10^{-4} \mathrm{sec}^{-1} \\
& \left(\text { as } \Omega=7.29 \times 10^{-5} \mathrm{sec}^{-1} \text { and } \varphi=511^{1 / 2^{\circ}}\right) \\
& f=2.5 \times 10^{-4} \mathrm{sec}^{-1} \\
& \left(\text { as } l_{\max }=4 \mathrm{ft} \mathrm{sec}^{-1} \text { and } \mathrm{C}=130 \mathrm{ft}^{1 / 2} \mathrm{sec}^{-1}\right) \\
& \alpha=1.20 \times 10^{-5} \mathrm{ft}^{-1}, h=26 \mathrm{ft} \text { and } \mathrm{L}=62 \text { miles. }
\end{aligned}
$$

Some of these values are obtained from Inglis and Allen (1957). From (14) we have :

$$
\begin{aligned}
& k_{1}=(0.40+0.07 i) \times 10^{-5}, \\
& k_{2}=(-0.40+1.13 i) \times 10^{-5} \mathrm{ft}^{-1}
\end{aligned}
$$

and from (15):

$$
m=0.19+0.34 i
$$

For (16) to be applicable to the Thames, we require from (11) that :

$$
\beta\left|k_{1}\right| b(o)<0.4 \sqrt{\omega^{2}+f^{2}},
$$

or roughly that $b(o)<50$ miles. Further, if reflected waves are taken into account, as in (27), we require from (11) and (24) that:

$$
\begin{array}{r}
\beta .\left|k_{2}\right| b(o)<0.4 \sqrt{\omega^{2}+f^{2}}, \\
\beta\left|k_{2}\right| b(\mathrm{~L})<0.04 \sqrt{\omega^{2}+f^{2}},
\end{array}
$$

or roughly that $b(o)<20$ miles and $b(\mathrm{~L})<2 \mathrm{mi}-$ les. In fact, $b(o)=4$ miles and $b(L)=200 \mathrm{ft}$, so the theory of $\S 2$ can be applied in the present example and should give a good approximation.

The Coriolis effect across the Thames Estuary in the vicinity of Southend $(x=0)$ is now calculated by the various formulae given in $\S 1$ and $\S 2$. 
Tout d'abord, l'application erronée des deux résultats de Kelvin du $\S 1$ donne ou $a \beta b / \sqrt{g h}$ ou $u_{10} \beta b / g$ pour la différence d'amplitude entre les deux rives de l'estuaire, $u=(1,05 \mathrm{~m} / \mathrm{s})$ étant l'amplitude du courant de marée à Southend. Ces formules montrent que les excédents d'amplitude sur la rive droite (nord) par rapport à la rive gauche (sud) sont de $12 \mathrm{~cm}$ et de $4,8 \mathrm{~cm}$ respectivement, sans qu'il y ait un déphasage entre les deux rives. L'écart entre ces deux valeurs est dû au fait que $u_{0} \neq \sqrt{(g / h)} a$ dans le cas étudié où les frottements et le rétrécissement de l'estuaire sont importants.

Dans le cas d'une onde progressive simple n'ayant pas une composante réfléchie, (20) donne :

$$
\left|\eta_{R}-\eta_{L}\right|=a b\left|m k_{1}\right|=5,1 \mathrm{~cm}
$$

en utilisant les valeurs données ci-dessus. [L'écart entre $u_{0} \beta b / g=4,8 \mathrm{~cm}$ et $\left|\eta_{\mathrm{R}}-\eta_{\mathrm{D}}\right|=5,1$ $\mathrm{cm}$ est dû au léger écart entre $u_{0}=1,05 \mathrm{~m} / \mathrm{s}$, valeur hypothétique obtenue à partir des données expérimentales, et la valeur de $u_{0}$, calculée à partir de (21).] Tandis que (18) ou (23) donnent :

$$
\left|\eta_{R}\right|-\left|\eta_{L}\right|=1,65 \mathrm{~cm}
$$

et montrent que le décalage en avant de la phase de $\eta_{R}$ par rapport à la phase de $\eta_{T}$ est d'environ 140 secondes. La différence d'amplitude n'est que d'environ un tiers de la dénivellation maximale.

Ensuite, on tient compte de la composante réfléchie de l'onde en faisant intervenir la condition limite à $x=\mathrm{L}$ (le barrage mobile à Teddington), (27) donne :

$$
\left|\eta_{\mathrm{R}}-n_{\mathrm{L}}\right|=5,5 \mathrm{~cm},\left|n_{\mathrm{R}}\right|-\left|\eta_{\mathrm{L}}\right|=1,5 \mathrm{~cm}
$$

le décalage de $\eta_{R}$ en avance sur $\eta_{I_{1}}$ étant d'environ 150 secondes. Dans l'exemple présent, on constate que l'influence de l'onde réfléchie est faible.

La faible différence d'amplitude, d'environ $1,5 \mathrm{~cm}(0,6 \%$ de l'amplitude de $2,44 \mathrm{~m})$ entre les deux rives de l'estuaire de la Tamise à Southend a peu de conséquences pratiques, mais on a choisi cet exemple parce que la largeur de l'estuaire de la Tamise est une fonction presque exponentielle de sa longueur, parce que sa profondeur est presque constante sur une grande partie de sa longueur et parce que l'estuaire est bien étudié. Dans des estuaires plus larges, la différance d'amplitude entre les deux rives ne se. rait pas aussi faible. Cependant, il est difficile de faire une comparaison entre la différence d'amplitude théorique et la différence observée puisque, en pratique, les résultats sont faussés par l'influence de la faible profondeur près des rives, par les irrégularités locales de la section transversale et par la courbure du chenal principal.
First, by the misapplication of Kelvin's two results given in $\S 1$ : the difference of amplitude across the estuary is given by either $a \beta b / \sqrt{g h}$ or $u_{0} \beta b / g$ where $u_{0}\left(=3.45 \mathrm{ft} \mathrm{sec}^{-1}\right)$ is the amplitude of the tidal current at Southend. These formulae show that the amplitude on the right (north) bank is greater than that on the left (south) bank by 4.8 ins and 1.9 ins respectively, with no phase difference across the estuary. The discrepancy between these two figures arises since $u_{0} \neq \sqrt{(g / h)} a$ in the present context where frictional resistance and taper of the estuary are important.

For a single progressive wave with no reflected component, $(20)$ gives :

$$
\left|\eta_{R}-\eta_{L}\right|=a b\left|m k_{1}\right|=2.0 \text { ins. }
$$

using the values above. (The difference between $u u_{0} \beta b / g=1.9$ ins and $\left|\eta_{l}-\eta_{c}\right|=2.0$ ins is due to the slight discrepancy between $u_{0}=3.45 \mathrm{ft} \mathrm{sec}^{-1}$ which was assumed for the first from experimental data and the calculated value of $u_{0}$ from (21).) While, from either (18), or (23), we have that :

$$
\left|\eta_{\mathrm{R}}\right|-\left|\eta_{\mathrm{L}}\right|=0.65 \mathrm{ins}
$$

and that $\eta_{R}$ has a phase lead of about 140 seconds over $\eta_{5}$. The difference in tidal amplitude is thus only about a third of the maximum difference in level.

Next, the reflected wave component is taken into account by means of the boundary condition at $x=\mathrm{L}$ (Teddington Weir), (27) gives :

$$
\left|\eta_{\mathrm{R}}-\eta_{\mathrm{L}}\right|=2.15 \mathrm{ins},\left|\eta_{\mathrm{R}}\right|-\left|\eta_{\mathrm{L}}\right|=0.60 \mathrm{ins} \text {, }
$$

with $\eta_{R}$ in advance of $\eta_{\mathrm{L}}$ by about 150 seconds. In the present example the influence of the reflected wave is seen to be small.

The small difference of about 0.6 ins in amplitude $(0.6 \%$ of the $8 \mathrm{ft}$ amplitude) across the Thames Estuary near Southend is of little practical consequence, but this illustrative example was chosen since the Thames Estuary is closely exponential in width, of approximately constant mean depth over much of its length and is well documented. In wider estuaries the variation in amplitude across the estuary would not be so trivial. It is difficult, however, to compare the theoretical difference of amplitude across an estuary with observation, since in practice the results are obscured by the effects of shallow water near the banks, local irregularities in the cross-section and curvature of the main stream. 
Enfin, on peut signaler le bon accord entre (27), qui néglige le faible effet de Coriolis, et le comportement observé de la marée le long de l'estuaire de la Tamise. Par exemple, une marée qui a une amplitude de 2,44 $\mathrm{m}$ à Southend (27), donne une amplitude de $3,08 \mathrm{~m}$ à London Bridge par rapport à la valeur observée de $3,12 \mathrm{~m}$, et le retard de phase à London Bridge par rapport à Southend est trouvé de 1 heure 32 minutes par le calcul et d'environ 1 heure 26 minutes par l'observation. L'amplitude du courant de marée à Southend, donnée par (28), est de $1,13 \mathrm{~m} / \mathrm{s}$, en face d'une valeur observée d'environ $1,05 \mathrm{~m} / \mathrm{s}$.

Ce fut M. G.H. Lean, de I'Hydraulics Research Station, D.S.I.R., qui démontra pour la première fois l'excellence de cette méthode pour le calcul des marées de la Tamise, et les valeurs de $\alpha$ et de $h$ qu'on utilise dans ce chapitre ont été tirées de son rapport inédit.

Les travaux décrits dans celte communication font partie du programme d'études de l'Hydraulics Research Board du Department of Scjentific and Industrial Research, et ont été présentés avec l'aimable autorisation du Directeur d'Hydraulics Research.
Finally, it is worth pointing out the satisfactory agreement between (27), neglecting the small Coriolis effect, and the observed tidal behaviour along the Thames Estuary. For example, for a tide which has an amplitude at Southend of $8 \mathrm{ft}$, (27) gives the amplitude at London Bridge as $10.1 \mathrm{ft}$ compared with an observed value of $10,25 \mathrm{ft}$, and the phase lag at London Bridge relative to Southend is $1 \mathrm{hr} 32 \mathrm{~min}$. by calculation compared with about $1 \mathrm{hr} 26 \mathrm{~min}$. by observation. The amplitude of the tidal current at Southend is given by (28) as $3.7 \mathrm{ft} \mathrm{sec}-1$ compared with an observed value of about $3.45 \mathrm{ft} \mathrm{sec}^{-1}$.

Mr. G. H. Lean of the Hydraulics Research Station, D.S.I.R., first showed how well the tides in the Thames could be calculated in this way; the values of $\alpha$ and $h$ used in this section are from his unpublished report.

The work described in this paper was carried out as part of the research programme of the Hydraulics Research Board of the Department of Scientific and Industrial Research, and is published with the permission of the Director of Hydraulics Research.

\section{REFERENCES}

Inglis (C. C.) and Allex (F. H.), 1957. "The regimen of the Thames estuary as affected by currents, salinities, and river flow."

Proc. Instn. Civ. Engrs., 7, 827.
Laxr (H.), 1932, "Hydrodynamies", 64h edition, Cambridge, $\$ 208$.

Thompson (W.), 1879. "On gravitational oscillations of rotating water".

Proc. R. S. Edin., 10, 92 .

\section{NOTRE FRONTISPIOE}

(Cf. p. 550)

AMPËRE (1775-1836)

Si Andre-Marie Ampere u’a jas été à proprement parler un hydraulicien, on ne saurait cependant oublier qu'il a laissé son nom à l'unité de débit de l'energie electrique, atijourd'hui si étroitement associée à l'énergie hydraulique que, lorsque on pense: aménagement, ou installation, "hydraulique $\%$, tout maturellement les mots ic hydro-électrique p viennent plutốt sous la plume, tant est devenu rare de nos jours l'usage direct des forces de l'eat comme énergie notrice.

Cette nutation d'une forme d'énergie à une autre phus souple, plus mobile et plus commole doit beancoup aux decouvertes et aux idées d'Anpère, et au trait de génie qui lui fit allier le magnétisme et l'electricité : sa clairvoyance et sa Incidité exceptonnelles, lorsqu'il posa en 1820 les principes de l'électromagnétisme permirent d'aboutir plus tard à la dynamo, à la géné ratrice, puis à l'alternateur de ros jours.

Son election a l'Académie des Sciences en 1814 suivit de peu sa brillante démonstration de la loi de Mariotte au cours de séance du 24 janvier 1914 de cette Compagnie. Beaucoup d socićtés savantes, d'Allemagne, de Grande-Bretagne, de Suède et de Suisse, shonorèrent en lélisant parmi leurs membres. Né à Poleymieux, près de Lyon, le 22 janvier 1775 , cet homme au doux visage et an sourire un peu triste, endeuillé pour la vi pat la fin tragique de son père sous la Terreur, durement atteint par des épreuves familiales successives, ce savant timide et crédule, atux distractions légendaires, apparait cependant comme l'un des esprits les plus brillants et les plus atudacieusement créateurs qui aient jantais marqué lenr trace dans li science

Ampère nourut ì Marseille, au cours d'un voyage, le 22 juin 1836.

\begin{abstract}
AMPERE (1775-1836)
Andre-Marie Ampere zoas not a hydratic engincer but his name avas given to the thit of electric current. Nowadays, electivic power has become so closely linked with hydraulic pozer an. so rare is it for water pozter to be thed as a direct source of energy that we readity use the word hyrolectrit rather than hydratis when referring to poser plants and developments. Ampere's discoveries and tideas, and the streak of getius which lod him to connect electricity weith magnetism did whuch to make it possible to transform the older form of enorgy thto the newe more flexible, more easily transmitted and mote convenien form. His estanciation of the frinciples of electromagnetisn in 1820 rasulted later in the developsnent of the dynamo, the generator and the present day alternator.

His brilliant proof of Mariotte's lare at a meeting of the Academie des Sciences on Jamury $24 \mathrm{th} 1814$ preceded his elec tion to that body later in the same year. Many leatned societies in Germany, Great Britain, Sreden and Stwiterland added to their reputations by making lim a nember.

Ampere zas bort at Poleymizux near Lyous on Jamary 22 ud 1775. This gente-faced man with the rather sad smile, had his whole life saddened by his father's death at the hands of the woolutionaries and by a sertes of family tragedics. Ife teas limid and credulons, and roell know for his absentmindedness. Hoctever, he toas one of the most brilliant and most andacionsty creatize minds to have left its mats on science.
\end{abstract}

He died on Juhe $22 n d 1836$ at Marseilles whilst travellug. 